\title{
ПОЛИТИЧЕСКИE HAУRИ
}

УДК 32.019 .5

ПОЛИТИКА ПОПУЛИСТОВ В ПЕРИОД ПАНДЕМИИ СOVID-19.

DOI: 10.31618/ESU.2413-9335.2020.6.73.691

Абрамян Артем Сергоевич

Московский государственный областной университет Аспирант 3 курса

POPULIST POLITICS DURING THE COVID-19 PANDEMIC.

Artem Abramyan

Moscow state regional University

\begin{abstract}
АННОТАЦИЯ
Целью статьи является определение основных мер популистов по борьбе с распроранением COVID 19 на примере Соединенных Штатов Америки и Италии. Исследование анализирует популистские лидеры во всем политическом спектре справились со вспышкой COVID-19. Наблюдение показывает как, на примере США, Италии такие как их оптимистическая предвзятость и самодовольство, двусмысленность и незнание науки. В ходе исследования проведен анализ предпринятых мер правительства Италии и Президента США. Результаты исследования позволяют использовать его материалы и теоретические результаты прежде всего в политологии. Также они могут быть применены в разработке специализированных курсов по изучению современных глобализационных процессов, политическому лидерству, развитию партий, а также по политике мультикультурализма.
\end{abstract}

\section{ANNOTATION}

The purpose of the article is to identify the main measures of populists to combat the removal of COVID 19 on the example of the United States of America and Italy. The study analyzes populist leaders across the political spectrum coped with the COVID-19 outbreak. The observation shows how, in the example of the United States, Italy such as their optimistic bias and complacency, ambiguity and ignorance of science. The study analyzes the measures taken by the Italian government and the US President. The results of the research allow us to use its materials and theoretical results primarily in political science. They can also be used in the development of specialized courses on modern globalization processes, political leadership, party development, and multiculturalism policy.

Ключевые слова: популизм, короновирус, COVID 19, политические технологии, политический кризис, Дональд Трамп, США, Италия. Italy.

Keywords: populism, coronovirus, COVID 19, political technologies, political crisis, Donald trump, USA,

\section{Введение}

Рост популизма во всем мире - например, в Соединенных штатах и Италии - отчасти способствовал глобальной неспособности властей адекватно реагировать на пандемию COVID-19 и привел мир к рецессии быстрее, чем ожидалось

К 5 мая по сведениям Всемирной организации здравоохранения Зисло зараженных коронавирусом в мире превысило 3,3 млн подтвержденных случаев заболевания и 238000 смертей от COVID-19 ${ }^{1}$. К настоящему времени пострадали 211 страны. Наихудший сценарий развития событий предполагает потенциал негативного экономического роста, в том числе в странах Европы и Северной Америки.

Почти треть заражений приходится на США. Там зарегистрировано почти 1,1 млн заражений. Количество смертей в Соединенных Штатах достигло 62406 ,

\begin{tabular}{|c|c|c|}
\hline Страна & Заболевших & Смертельные случаи \\
\hline США & 1212955 & 69925 \\
\hline Испания & 248301 & 25428 \\
\hline Италия & 211938 & 29079 \\
\hline Великобритания & 190584 & 28734 \\
\hline Франция & 169462 & 25201 \\
\hline Германия & 166152 & 6993 \\
\hline Россия & 155370 & 1451 \\
\hline
\end{tabular}

1 [Электронный ресурс] - Режим доступа: https://www.who.int/ 1023500457229070336 (дата обращения: 02.05.2020) 


\section{Популизм как теория}

Популизм важно рассматривать как идеологию, организованную вокруг двух основных убеждений:

1. антиистеблишментское общество делится на две противоположные группы: «народ» (чистый) и «элита» (коррумпированная)

2. политика должна выражать «общую волю» «народа» ${ }^{3}$.

Популистские лидеры предполагают, что они одни представляют волю народа и могут решать угрозы обществу от имени народа. Они могут сделать это путем выявления социальнокультурных угроз обществу, таких как иммиграция, или социально-экономических угроз, таких как глобализация ${ }^{4}$.

\section{Борьба с короновирусом в США}

В соотвествии со статистикой от ВО3 можно увидеть, что первое место по числу зараженных занимают США, где президентом является Д. Трамп,

А поскольку сверхдержава, Соединенные Штаты, управляется популистским лидером, который вернулся к изоляционизму, глобальная безопасность здравоохранения находится под угрозой. Снижение лидерства США при президенте Д. Трампе подорвало антикризисное управление и поставило мир под угрозу.

Когда изображения начальной эпидемии COVID-19 появились из Китая и были разбросаны по глобальным новостным лентам и в социальных сетях в январе 2020 года, Трамп в США был оптимистичен, что вирус не повлияет на его страну. Несмотря на свой огромный потенциал, запоздалый ответ администрации Трампа на сдерживание COVID-19, создал своевременную фискальную политику, распределив ресурсы и введя меры по смягчению последствий в январе и феврале, вызвал всплеск числа случаев в США до самого высокого в мире.

Администрация Д. Трампа практически игнорировала предупреждения в начале вспышки, затягивая подготовку системы здравоохранения, в том числе медицинских испытательных учреждений. В результате, в США один из самых высоких показателей смертности от COVID-19 в мире.

B нынешней пандемии COVID-19 популистские лидеры были чрезмерно оптимистичны, оценивая свою компетентность в реагировании на пандемию. Они показали, что

2 Mudde C. Populist Zeitgeist / C. Mudde // Government and Opposition. - 2004. - No. 39 (4). - P. 543.

3 Малько А. Популизм как тормоз демократии //Общественные науки и современность. - 2004. - № 1 . - C. 104-111. - C. 106

4 Мюллер Я.-В. Что такое популизм? / Я.-В. Мюллер. - М.: Изд. дом Высшей школы экономики, 2018. - С. 37-38.

5 [Электронный ресурс] - Режим доступа: https://www.politico.com/news/2020/03/17/trump- склонны к самоуспокоенности, форме когнитивной предвзятости, которая заставляет кого-то считать, что они менее других подвержены воздействию возникающих кризисов.

В сравнении данных стран от этого, правительствам таких стран, как Германия, Канада и Новая Зеландия, потребовалось меньше времени для принятия соответствующих мер. Германия провела агрессивное тестирование COVID-19 (со скоростью 160000 тестов в неделю), помогая стране выявлять случаи заболевания ранее. Там уровень смертности остался на уровне около 1,6\% . Широкая стратегия тестирования также помогла Канаде сохранить свой уровень смертности на уровне 1,8\%. Новая Зеландия последовательно проводит тесты и сохраняет свой уровень морали намного ниже $1 \%$.

Издание Politico заявляло, что еще в феврале специалисты уговаривали Трампа принять неотложные меры для предотвращения вспышки инфекции, однако президент неизменно говорил, что «у него все под контролем». Позже он стал утверждать, что во всем виновата ВО3, которая неправильно оценила уровень смертности, а сам он с самого начала понимал всю серьезность происходящего 5 .

Вместо того чтобы продемонстрировать приверженность доказательствам и выслушать экспертов по предмету, Трамп отвлек американскую общественность, используя символический ответ на COVID 19 - Трамп объявил 15 марта днем молитвы за пострадавших от коронавируса. Глава государства призвал людей всех вероисповеданий и религиозных традиций вознести молитвы за пострадавших, включая людей, которые потеряли близких или понесли ущерб 6

В период пика заболеваемости и ущерба проявляется типичная методика поиска врагов и чужих в борьбе. Д. Трамп первоначально заявил о вине Всемирной организаии здравохраниня за упущение момента борьбы с вирусом и неоднократно угрожал и обвинял правительство Китая в искусственно созданном вирусе.

Популистские правительства печально известны тем, что «заставляют замолчать» науку . Это объясняется тем, что политика, основанная на фактических данных, несовместима с их подходом к государственной политике.

shifting-coronavirus-tone- 134100

1023500457229070336 (дата обращения: $02.05 .2020)$

6 Трамп объявил 15 марта днем молитвы за пострадавших от коронавируса [Электронный pecypc] - Режим доступа: https://www.golosameriki.ru/a/prayer-for-all-americans-affected-by-

coronavirus-pandemic/5329676.html обращения: 02.05.2020) (дата 


\section{Ситуация в Италии}

Италия так же известна ростом популистов и по мнению исследователей кабинет министров под руководством Джузеппе Конте является первым популистским правительством в Западной Европе ${ }^{7}$.

В Италии Маттео Сальвини, лидер правой партии Лига Севера, использовал COVID-19 для развития ксенофобии. Сальвини распространил видеозапись прибытия мигрантского судна в Италию, ложно намекая на то, что мигранты несут ответственность за вспышку заболевания. Наряду с другими крайне правыми лидерами в Европе, Сальвини также использовал закрытие границ Европы как еще одну возможность очернить Европейский Союз и его приверженность свободному передвижению людей.

Опыт Италии может очень хорошо предсказать, как популизм будет развиваться вслед за пандемией коронавируса, как стоящей поддержки популистских партий в данный момент, так и потенциально подталкивающей эти партии к принятию более националистических и откровенно авторитарных позиций.

Как и во всем мире в Италии, пандемия разрушает многие традиционные столпы популистской поддержки. В глобальной пандемии, подобной COVID-19, популистские лидеры, такие как Трамп, не решались повернуть вспять курс и позволить научным знаниям направлять их решения в смягчении кризиса здравоохранения.

Когда эти лидеры, наконец, признали научное консультирование, общественность была обременена высокими издержками осуществления экстремальных политических мер. Поскольку изменение политики часто было слишком поздно,наиболее вероятным и простым вариантом сдерживания COVID-19 является применение драконовских мер.

Например, Отложенные действия по сдерживанию COVID-19, которые привели к драматическим всплескам смертей, подтолкнули правительство Италии, состоящее из беспокойной коалиции между антиистеблишментским движением «Пять звезд» и левоцентристской Демократической партией, к введению жестких ограничений, навязываемых полицией и военными.

Когда коронавирус поразил весь мир, популистские тенденции начали сотрясаться. Правительства, которые еще несколько месяцев назад были наделены полномочиями в рамках антииностранной политики и лозунгов, начали просить о помощи. Международные организации, такие как Организация Объединенных Наций и Всемирная организация здравоохранения, которые были высмеяны президентом Трампом и другими популистскими правительствами, набирают известность.

Несмотря на все беспорядки, сдерживающие появление новой инфекционной болезни,

7 The Populists Take Rome | RealClearPolitics [Электронный ресурс] - Режим доступа: https://www.nytimes.com/2018/05/24/opinion/populis социально-политические споры о том, как справиться с инфекционным кризисом, очень сильно разделены. В некоторых странах, включая Соединенные Штаты, политические оппозиции указывают пальцем на то, как администрация Трампа действовала безответственно в отношении продолжающейся пандемии. Затем в других странах, таких как Италия, превратили «пандемии» в проблему иммиграции и иностранных дел, обвиняя правящее правительство в том, что оно ставит население под угрозу в первую очередь.

Коронавирус меняет политический ландшафт Европы. В результате этого, вероятно, пострадают многие существующие популистские партии и лидеры. Но, как подчеркивает случай Италии, было бы неразумно предполагать, что то, что последует за сегодняшними популистами, приведет к выгодам для либеральной демократии.

Общая природа кризиса COVID-19 подрывает еще один ключевой драйвер популизма: политику идентичности. Популисты уже давно пытаются внушить господствующим группам населения страх, что их статус находится под угрозой со стороны аутсайдеров или групп меньшинств, таких как приток сирийских мигрантов в Европу. Но коронавирус не знает границ и поражает все общество, независимо от расы или идентичности.

\section{Вывод}

Коронавирус является испытанием для национальных лидеров и международного сотрудничества, и он уже привнес драматическую события в политические системы. Пока еще слишком рано говорить о том, будет ли это способствовать возникновению условий, которые углублят или подорвут политику западных популистов. Однако президент Д. Трамп имеет привчку обвинять СМИ в фальшивых новостях и кампаниях дезинформации. Их незнание науки доходит до того, что истина и ложь не имеют четких границ. В катастрофах использование такой двусмысленности для пропаганды политической повестки дня усиливается.

Исследования показывают, что тенденция популистских правительств отрицать научное знание по сложным вопросам, таким как здоровье и окружающая среда, ради экономической и политической выгоды глубоко укоренилась.

В глобальной пандемии, подобной COVID-19, популистские лидеры, такие как Трамп, не решались повернуть вспять курс и позволить научным знаниям направлять их решения в смягчении кризиса здравоохранения.

Популизм делит общество на две однородные группы : настощие люди и коррумпированная элита. В нынешнем кризисе это антагонистическое обрамление не находит отклика. В отличие от обвинений элит, который ускорил популистский всплеск в Европе, коронавирус не может быть легко обвинен в элите. Во всяком случае, срочность и

ts-rome-five-star-movement.html (дата обращения: 02.05 .2020 ) 
масштабность этого общего кризиса потребовали единства и уменьшили поляризацию, которую процветают популисты.

Когда эти лидеры, наконец, признали научное консультирование, общественность была обременена высокими издержками осуществления экстремальных политических мер. Поскольку изменение политики часто было слишком поздно,наиболее вероятным и простым вариантом сдерживания COVID-19 является применение драконовских мер.

\section{Список литературы:}

1. Mudde C. Populist Zeitgeist / C. Mudde // Government and Opposition. - 2004. - No. 39 (4). - P. 543 ;

2. The Populists Take Rome | RealClearPolitics [Электронный pecypc] - Режим доступа: https://www.nytimes.com/2018/05/24/opinion/populis ts-rome-five-star-movement.html (дата обращения: 02.05.2020);

УДК:328

ГРНТИ:11.15.19
3. Малько А. Популизм как тормоз демократии //Общественные науки и современность. - 2004. - № 1 . - С. 104-111. - С. 106;

4. Мюллер Я.-В. Что такое популизм? / Я.-В. Мюллер. - М.: Изд. дом Высшей школы экономики, 2018. - С. 37-38;

5. Трамп объявил 15 марта днем молитвы за пострадавших от коронавируса [Электронный pecypc] - Режим доступа: https://www.golosameriki.ru/a/prayer-for-all-americans-affected-bycoronavirus-pandemic/5329676.html

(дата обращения: 02.05.2020);

6. [Электронный ресурс] - Режим доступа: https://www.politico.com/news/2020/03/17/trumpshifting-coronavirus-tone- 134100

1023500457229070336 (дата обращения: 02.05.2020);

7. [Электронный ресурс] - Режим доступа: https://www.who.int/ 1023500457229070336 (дата обращения: 02.05.2020)

ОБРАЗ «РУССКОГО ВРАГА» В СОВРЕМЕННОМ ВНЕШНЕПОЛИТИЧЕСКОМ ДИСКУРСЕ США: ДИСКУРС-АНАЛИЗ СМИ

Галдина Е.В.

Московский Государственный Лингвистический Университет Студентка IV курса

\title{
THE IMAGE OF THE "RUSSIAN ENEMY" IN THE US FOREIGN POLICY DISCOURSE: MEDIA DISCOURSE ANALYSIS
}

\author{
Evgenia Galdina \\ Moscow State Linguistic University \\ 4th year student
}

\section{АННОТАЦИЯ}

В данной статье рассматривается методология создания и трансляции в политическое массовое сознание образа «врага» в современном внешнеполитическом дискурсе США. Ситуация на международной арене оказывает значительное влияние на восприятие социумом другого государства. Данный политический феномен способен отразить настроения социума по отношению к внешней политике, а также степень его влияния на психологическое состояние общества. СМИ стали «четвертой властью», и являются инструментом трансляции образа «врага» в массовое политическое сознание. Автор проводит анализ медиаобраза «русского врага» на примере статей крупных американских изданий (Eurasia Review, The New York Times, The Washington Post) и выявить специфику его формирования.

\section{ANNOTATION}

In the article the methodology of creating and translating into the political mass consciousness the image of the "enemy" in the modern foreign policy discourse of the United States is discussed. The situation in the international arena has a significant impact on the perception of another state. This political phenomenon is able to reflect the mood of society in relation to foreign policy, as well as the degree of its influence on the psychological state of society. The media have become the "fourth power", and are an instrument for translating the image of the "enemy" into the mass political consciousness. The author analyzes the media image of the "Russian enemy" on the example of articles from major American publications (Eurasia Review, The New York Times, The Washington Post) and reveals the specifics of its formation.

Ключевые слова: образ врага, массовое политическое сознание, СМИ, внешнеполитические дискурс

Keywords: image of the enemy, mass political consciousness, media, foreign policy discourse

Современный внешнеполитический дискурс США основывается на внешнеполитических стратегиях США и национальных интересах. В последней «Стратегии национальной безопасности США» (далее - Стратегия) от 2018 года, Россия объявлена ключевым соперником США и 